\title{
METABOLIC STUDIES OF THE CHANGES IN BODY ELECTROLYTE AND DISTRIBUTION OF BODY WATER INDUCED EXPERIMENTALLY BY DEFICIT OF EXTRACELLULAR ELECTROLYTE ${ }^{1}$
}

\author{
By DANIEL C. DARROW AND HERMAN YANNET \\ (From the Department of Pediatrics, Yale University School of Medicine, New Haven)
}

(Received for publication March 31, 1936)

The immediate effects of removing extracellular electrolyte from animals without changing the total quantity of body water were described in a recent publication (1). The clinical evidences of dehydration which occurred were shown to be brought about by the shift of water from the extracellular to intracellular fluids.

In the present investigations the depletion of extracellular electrolyte was allowed to persist for seven days. The mechanism of adjustment was studied by frequent blood analyses and determination of the balances of nitrogen, water and electrolyte. Together with more accurate knowledge of the concentration and volumes of intracellular and extracellular water and electrolytes (2), the data are suitable for testing certain hypotheses concerning the factors controlling the distribution and balance of body water and electrolyte.

\section{EXPERIMENTAL METHODS}

Dog 1 (Experiments 3 and 5) was a thin, active male who ate his food well when normal; Dog 2 (Experiments 2 and 4) was a fat female who took the diet less well. Except for the period of deficit of extracellular electrolyte, when food was refused, both dogs were in approximate nitrogen equilibrium or showed a slight positive balance.

The animals were fed the kennel food until a week before the experiments were started, when an artificial diet was given. One kilogram of this diet consisted of commercial casein, .280 grams; sucrose, 250 grams; commercial dextrin, 250 grams; crisco, 200 grams and agar, 20 grams. By analysis, one kilogram contained: nitrogen, 37.8 grams; sodium, $6.4 \mathrm{mM}$; chloride, 11.1 $\mathrm{mM}$.; potassium, $2.9 \mathrm{mM}$. and phosphorus, 71.5 $\mathrm{mM}$.

\footnotetext{
1 Read in abstract before the American Society for Clinical Investigation in Atlantic City, N. J., May 6, 1935.
}

After a preliminary control period, the dogs were deprived of extracellular electrolyte without significant change in total body water in the following manner. About 100 cubic centimeters per kilogram of body weight of five per cent solution of glucose was injected into the peritoneal cavity. After four hours when considerable amounts of extracellular electrolytes had diffused into the peritoneal cavity, a volume of fluid approximately equal to that injected was removed with a trocar. All food was removed from the cage 18 hours before the peritoneal injection, and feeding was not resumed until the fast had lasted 36 hours. After 7 days, the deficit of extracellular electrolyte was replaced by injecting into the peritoneal cavity a definite amount of a saline solution usually of double physiological strength. The amount of sodium chloride which was injected was greater than that which had previously been removed. In Experiments 2, 3 and 4 the animals were then given only the low salt diet for 7 days and in Experiment 5, for 14 days. In Experiments 3 and 5, subsequently, capsules containing definite amounts of potassium chloride were given daily for 7 days. In Experiment 5, during the last 2 weeks in addition to capsules containing potassium chloride, a total of 350 grams of wheat germ (Embo) were given. ${ }^{2}$ The wheat germ taken contained K, 89 mM.; P, $110 \mathrm{mM}$. and $\mathrm{N}, 18.6$ grams. The preparation did not contain significant amounts of sodium and chloride.

For convenience, the periods will be labeled as follows : Period A, preliminary control; Period B, electrolyte depletion; Period C, administration of sodium chloride; Period $\mathrm{D}$, administration of $\mathrm{KCl}$ and Period $\mathrm{E}$, final control.

At the beginning and end of each period and

2 The wheat germ was given as a source of vitamin B, since the diet may be too low in B for prolonged experiments. 
at certain other times, analyses of serum and defibrinated blood were carried out.

The methods and calculations of the blood analyses are the same as those used in a previous study (1). Stools and urine were analyzed by the following methods: nitrogen, Kjeldahl (3); chloride, Van Slyke (4); phosphorus, Mackay and Butler (5); sodium, Butler and Tuthill (6) after the removal of potassium as described by Hald (7) ; potassium, Hald's modification (7) of the method of Shohl and Bennet.

The balance of water was determined by the method of Peters, Kydd and Lavieties (8). The weekly output of calories according to Cowgill (9) would be 4000 for Dog 1 and 5400 for Dog 2 . The former figure agrees with the intake for maintenance of Dog 1 . The intake for maintenance of Dog 2 was not determined. In calculating the balance of water, the output of calories was assumed to follow the prediction formula of Cowgill and the same figure was used in all periods including the $B$ periods when food was refused. If the caloric outputs were less during these periods, as is likely, the loss of water in these periods would be somewhat greater than those indicated in the table. The water balances are considered to have a possible error of \pm 0.075 liter.

Short protocols for each experiment are appended at the end of the paper.

\section{RESULTS}

As can be seen from the outline of the experimental procedures, the data were collected so as to give information concerning the change in serum electrolyte and the balance of certain constituents of body fluids; (1) when loss of extracellular electrolyte is induced (B periods), (2) when the deficit of extracellular electrolyte is replaced ( $C$ periods), and (3) when deficits of nitrogen, phosphorus and potassium are restored (D periods).

\section{Symptoms accompanying the procedures}

During the periods of deficit of extracellular electrolyte, the symptoms and signs of dehydration previously described (1) persisted until the loss of sodium chloride was replaced. The animals with large deficits of sodium chloride (Experi- ments 2, 3 and 4) refused to eat during the entire $B$ periods. Spontaneous recovery of these animals seemed unlikely. Other dogs in similar states vomited if food was in the stomach when the deficit was produced; and in one case after the deficit had persisted 7 days the dog vomited capsules of sodium chloride about 5 minutes after administration. Although salt added to the drinking water would probably have lead to recovery, this procedure was not tried.

The oliguria previously noted (1), continued for about 12 to 24 hours. During the period of oliguria little or no water was taken. Thereafter water was drunk in such amounts that water intake and urine output approached that considered characteristic of starvation. In spite of the relatively normal fluid intake, the signs and symptoms of dehydration were unaffected. These observations are mentioned in order to emphasize the following points: (1) dehydration is a phenomenon which does not involve body water alone; (2) diuresis does not develop under certain conditions characterized by a relative excess of water in relation to electrolyte; (3) thirst is not an obligatory accompaniment of dehydration; (4) water intake and urine output may be normal in the presence of dehydration.

In Experiment 5 in which the quantity of extracellular electrolyte removed was considerably less, the symptoms and signs of dehydration were less marked. The dog's activity was but little affected; food was refused for only two days and was taken in normal amounts after 5 days.

Following the restoration of the deficit of extracellular electrolyte by the intraperitoneal injection of a solution of sodium chloride, the signs and symptoms of dehydration rapidly disappeared in all experiments. Food and water were taken in normal amounts, and the dogs behaved in a normal manner throughout the remainder of the experiments.

\section{The changes in concentration of serum electrolyte}

Table I gives the concentrations of serum electrolyte per kilogram of water while all other values are expressed in per cent by volume. All samples of blood were withdrawn in the morning which marked the end of the previous 24 hours. 
TABLE I

Concentration of serum electrolyte per kilogram of water

\begin{tabular}{|c|c|c|c|c|c|c|c|c|c|}
\hline \multirow{2}{*}{$\begin{array}{l}\text { Exper- } \\
\text { ment } \\
\text { number } \\
\text { and } \\
\text { period }\end{array}$} & \multirow{2}{*}{ Day } & \multicolumn{5}{|c|}{ Serum } & \multicolumn{3}{|c|}{ Cell } \\
\hline & & Water & $\begin{array}{l}\text { Pro- } \\
\text { tein }\end{array}$ & Chloride & Sodium & $\begin{array}{l}\text { Blear- } \\
\text { bonate }\end{array}$ & $\begin{array}{l}\text { Vol- } \\
\text { ume }\end{array}$ & $\begin{array}{l}\text { Pro- } \\
\text { tein }\end{array}$ & Water \\
\hline & & $\begin{array}{l}\text { per } \\
\text { cent }\end{array}$ & $\begin{array}{l}\text { per } \\
\text { cent }\end{array}$ & $\begin{array}{l}\text { mM. per } \\
\text { liter of } \\
\mathrm{H}_{2} \mathrm{O}\end{array}$ & $\begin{array}{l}\text { mM. per } \\
\text { liter of } \\
\mathrm{H}_{2} \mathrm{O}\end{array}$ & $\begin{array}{l}\text { mM. per } \\
\text { liter of } \\
\mathrm{H}_{2} \mathrm{O}\end{array}$ & per & $\begin{array}{l}\text { per } \\
\text { cent }\end{array}$ & $\begin{array}{c}\text { per } \\
\text { cent }\end{array}$ \\
\hline$\stackrel{\text { 2A }}{\mathbf{B}}$ & $\begin{array}{l}7 \\
1 \\
3 \\
7 \\
3\end{array}$ & $\begin{array}{l}93.3 \\
92.7\end{array}$ & $\begin{array}{l}6.1 \\
8.3 \\
8.1 \\
7.0 \\
5.5\end{array}$ & $\begin{array}{r}116 \\
92 \\
111\end{array}$ & $\begin{array}{l}160 \\
138 \\
136 \\
134 \\
151\end{array}$ & $\begin{array}{l}24.3 \\
24.4\end{array}$ & $\begin{array}{l}52.5 \\
65.1 \\
57.9 \\
55.7 \\
11.1\end{array}$ & $\begin{array}{l}36.3 \\
33.6 \\
34.9 \\
32.6 \\
33.0\end{array}$ & $\begin{array}{l}70.7 \\
67.8\end{array}$ \\
\hline 3A & $\begin{array}{l}5 \\
1 \\
3 \\
5 \\
7\end{array}$ & 93.3 & $\begin{array}{l}6.8 \\
8.1 \\
7.7 \\
7.5 \\
7.4\end{array}$ & $\begin{array}{r}116 \\
91 \\
92 \\
94 \\
94\end{array}$ & $\begin{array}{l}157 \\
129 \\
135 \\
136 \\
140\end{array}$ & 23.7 & $\begin{array}{l}54.5 \\
62.8 \\
60.4 \\
60.0 \\
58.4\end{array}$ & $\begin{array}{l}34.9 \\
33.0 \\
33.0 \\
34.0 \\
33.6\end{array}$ & 71.6 \\
\hline $\begin{array}{l}\mathbf{C} \\
\mathbf{D} \\
\mathbf{E}\end{array}$ & $\begin{array}{l}1 \\
7 \\
7 \\
7\end{array}$ & $\begin{array}{l}93.5 \\
93.3 \\
93.5\end{array}$ & $\begin{array}{l}4.8 \\
6.1 \\
6.1 \\
6.3\end{array}$ & $\begin{array}{l}109 \\
119 \\
118 \\
115\end{array}$ & $\begin{array}{l}148 \\
154 \\
155 \\
147\end{array}$ & $\begin{array}{l}21.0 \\
21.5 \\
23.5\end{array}$ & $\begin{array}{l}36.9 \\
43.0 \\
48.0 \\
\mathbf{4 8 . 9}\end{array}$ & $\begin{array}{l}33.8 \\
33.1 \\
32.2 \\
33.3\end{array}$ & $\begin{array}{l}72.1 \\
72.0 \\
71.8\end{array}$ \\
\hline AA & $\begin{array}{l}5 \\
1 \\
3 \\
5 \\
7 \\
1 \\
3 \\
7 \\
7\end{array}$ & $\begin{array}{l}93.0 \\
91.5 \\
91.7 \\
92.1 \\
92.6 \\
94.5 \\
93.6 \\
93.7 \\
94.0\end{array}$ & $\begin{array}{l}6.5 \\
7.8 \\
8.2 \\
7.8 \\
7.1 \\
5.2 \\
5.8 \\
5.8 \\
5.5\end{array}$ & $\begin{array}{r}116 \\
97 \\
94 \\
94 \\
90 \\
101 \\
109 \\
113 \\
117\end{array}$ & $\begin{array}{l}159 \\
144 \\
139 \\
139 \\
136 \\
137 \\
154 \\
155 \\
158\end{array}$ & $\begin{array}{l}27.9 \\
\\
25.3 \\
24.1\end{array}$ & $\begin{array}{l}57.2 \\
68.8 \\
62.2 \\
60.1 \\
55.0 \\
41.9 \\
43.5 \\
41.5 \\
42.4\end{array}$ & $\begin{array}{l}\mathbf{3 5 . 2} \\
\mathbf{3 3 . 8} \\
\mathbf{3 3 . 5} \\
33.1 \\
33.1 \\
\mathbf{3 3 . 1} \\
\mathbf{3 3 . 8} \\
\mathbf{3 4 . 2}\end{array}$ & \begin{tabular}{|l}
72.0 \\
72.2 \\
71.2 \\
72.5 \\
72.6 \\
72.8 \\
72.2 \\
$\mathbf{7 1 . 8}$
\end{tabular} \\
\hline $\begin{array}{r}\mathbf{B A} \\
\mathbf{B} \\
\mathbf{C} \\
\mathbf{D}\end{array}$ & $\begin{array}{r}7 \\
7 \\
7 \\
14 \\
7 \\
14\end{array}$ & $\begin{array}{l}93.0 \\
92.5 \\
93.7 \\
93.2 \\
93.0\end{array}$ & $\begin{array}{l}6.9 \\
7.5 \\
6.5 \\
6.6 \\
8.5\end{array}$ & $\begin{array}{l}118 \\
110 \\
119 \\
120 \\
115 \\
113\end{array}$ & $\begin{array}{l}158 \\
151 \\
119 \\
153 \\
153 \\
151\end{array}$ & & $\begin{array}{l}55.7 \\
59.3 \\
48.6 \\
52.3 \\
56.1 \\
57.7\end{array}$ & $\begin{array}{l}35.1 \\
34.2 \\
35.5 \\
32.6 \\
33.5\end{array}$ & $\begin{array}{l}71.4 \\
72.2 \\
73.7 \\
73.0 \\
73.0\end{array}$ \\
\hline
\end{tabular}

The blood findings demonstrate the effects of adjustments taking place during that day.

The immediate changes in the blood produced by loss of extracellular electrolyte are indicated by the samples taken at the end of the first day of Period B; i.e., about 18 hours after the production of the deficit of extracellular electrolyte. The changes to be noted are essentially the same as those described previously for samples taken about 4 hours after the production of the deficit (1). The blood became concentrated as is evidenced by the increased proportion of red cells in whole blood. This concentration resulted chiefly from loss of plasma water as is indicated by the increased concentration of proteins in serum. Increase in erythrocytic water is demonstrated by decrease in concentration of cellular proteins as well as direct determinations of cell water by drying blood and serum. The concentration of serum chloride and sodium was greatly reduced.

The mechanism of these changes was discussed previously (1). Briefly, the alterations are brought about first, by a loss of sodium and chloride and second, by shift of water from extracellular into intracellular spaces. This transfer of water is necessary to satisfy the disturbed osmotic relationship between intracellular and extracellular fluids which is produced when loss of electrolyte takes place from extracellular fluids without loss of water or loss of intracellular electrolyte.

In Experiments 2, 3 and 4, in which marked deficit of electrolyte was induced, the physiological adjustments during the week following these losses were essentially alike as may be observed from the samples of blood taken during the $B$ periods. As measured by the concentrations of sodium in serum, the osmotic pressure of body fluids remained at low levels throughout the period of deficit. In Experiment 3, a slight increase in concentration of serum sodium occurred but, in Experiments 2 and 4 but little change in serum sodium was found. In all three experiments the concentrations of serum proteins and red cells in blood returned towards normal.

The decrease in concentration of protein in serum and of erythrocytes in blood cannot be interpreted directly as changes brought about by increase in plasma water. Presumably part of the changes are produced by the withdrawal of blood for examination. Exact interpretation is impossible because of the likelihood of destruction or production of these constituents of blood during the periods of observation. The decrease in their concentration which was found on giving sodium chloride would indicate that plasma water remained low throughout the $B$ periods.

In Experiment 5, in which the deficit of extracellular electrolyte was less, the concentration of sodium and chloride in serum returned more nearly to the normal level at the end of the $B$ periods and before the administration of sodium chloride. The increase in concentration of proteins in serum and red cells in blood was about as great at the end of the $B$ periods as it was in the other experiments.

In all experiments, restoration of extracellular electrolyte brought the concentration of serum electrolyte to approximately normal levels. Experiments 3 and 4 indicate that at first the plasma volume was increased beyond normal. During the final periods when potassium chloride was 
given, no significant changes in serum electrolyte were found.

\section{The balances of nitrogen, water and electrolyte}

The data on the balances of nitrogen, water and electrolytes are summarized in Table II. A1though the outputs were determined separately on urines and stools, it was not thought necessary to give these values. The total output may be derived by subtracting the balance from the intake. Since the losses by the stools were small, most of the excretion may be assumed to have occurred by way of the urine. (The stool nitrogen was about 1 gram per week; sodium, 1 to $5 \mathrm{mM}$.; chloride, less than $1 \mathrm{mM}$.; phosphorus, 1 to $7 \mathrm{mM}$. and potassium, 1 to $5 \mathrm{mM}$.) The interpretations will not depend on the route of excretion.

It is necessary to point out that loss of appetite during the $\mathrm{B}$ periods led to absolufe starvation in all experiments except number 5. For this reason, the changes in body electrolyte accompanying the deficit of extracellular electrolyte cannot be considered to be pure responses to disturbed osmotic relationships but are complicated by the changes associated with starvation.

During the B periods, the losses of chloride and sodium were about 25 per cent of the total amounts of these ions in extracellular fluids in Experiments 2, 3 and 4 and about 18 per cent in Experiment 5. These proportions are based on an assumed initial volume of extracellular fluids equal to 27 per cent of the body weights (2).

In Experiments 2, 3 and 4 following the losses of sodium and chloride, a marked loss of body water occurred which was replaced to but a limited extent during the $\mathrm{C}$ periods. Nevertheless, the retentions of sodium and chloride in the $\mathrm{C}$ periods almost exactly replaced the previous deficits of these ions. Considerable losses of nitrogen, phosphorus and potassium accompanied the losses of water in the $B$ periods. With replacement of extracellular electrolyte during the $C$ periods and return of appetite, the losses of nitrogen and phosphorus ceased, but potassium continued to be excreted during the $\mathrm{C}$ periods. When $\mathrm{KCl}$ was given in the $\mathrm{D}$ periods, large retentions of potassium occurred.

In Experiment 5, but little nitrogen, phosphorus and potassium were lost in the $B$ periods. Nevertheless, a large amount of body water was excreted. During the $\mathrm{C}$ periods, extracellular electrolyte was restored without a significant change in body water. Thereafter large amounts of ni-

TABLE II

Intake and balance of water and electrolyte

\begin{tabular}{|c|c|c|c|c|c|c|c|c|c|c|c|c|c|c|c|c|}
\hline \multirow{2}{*}{$\begin{array}{c}\text { Experiment } \\
\text { number } \\
\text { and } \\
\text { period }\end{array}$} & \multirow{2}{*}{ Days } & \multirow{2}{*}{ Weight } & \multirow{2}{*}{ Urine } & \multirow{2}{*}{ Food } & \multicolumn{6}{|c|}{ Intake } & \multicolumn{6}{|c|}{ Balance } \\
\hline & & & & & Water & $\mathbf{N}$ & $\mathbf{P}$ & $\mathrm{Na}$ & $\mathrm{Cl}$ & $\mathbf{K}$ & Water & $\mathrm{N}$ & $\mathbf{P}$ & $\mathrm{Na}$ & $\mathrm{Cl}$ & $\mathbf{K}$ \\
\hline $\begin{array}{ll}2 & \mathrm{~A} \\
2 & \mathrm{~B} \\
2 & \mathrm{C}\end{array}$ & $\begin{array}{l}7 \\
7 \\
5\end{array}$ & $\begin{array}{c}\text { kilos } \\
12.7 \\
11.6 \\
11.4\end{array}$ & $\begin{array}{l}\text { liters } \\
0.62 \\
0.68 \\
1.00\end{array}$ & $\begin{array}{c}\text { grams } \\
402 \\
0 \\
338\end{array}$ & \begin{tabular}{l|} 
liters \\
1.43 \\
1.69 \\
2.31
\end{tabular} & $\begin{array}{c}\text { grams } \\
15.2 \\
0 \\
12.8\end{array}$ & $\begin{array}{r}m M \\
29 \\
0 \\
24\end{array}$ & $\begin{array}{r}m M . \\
3 \\
0 \\
105\end{array}$ & \begin{tabular}{|r|}
$m M$ \\
5 \\
0 \\
107
\end{tabular} & \begin{tabular}{|r|}
$m M$ \\
1 \\
0 \\
1
\end{tabular} & $\begin{array}{c}\text { liters } \\
+0.04 \\
-0.58 \\
+0.26\end{array}$ & $\begin{array}{l}\text { grams } \\
-6.4 \\
-26.5 \\
+3.3\end{array}$ & $\begin{array}{r}m M . \\
-12 \\
-60 \\
0\end{array}$ & $\begin{array}{l}m M . \\
-4 \\
-94 \\
+83\end{array}$ & $\begin{array}{l}m M . \\
+1 \\
+77 \\
+60\end{array}$ & $\begin{array}{l}\overline{m M .} \\
=\quad 1 \\
=\quad 20 \\
-\quad 27\end{array}$ \\
\hline $\begin{array}{ll}3 & \mathrm{~A} \\
3 & \mathrm{~B} \\
3 & \mathrm{C} \\
3 & \mathrm{D} \\
3 & \mathrm{E}\end{array}$ & $\begin{array}{l}4 \\
7 \\
7 \\
7 \\
7\end{array}$ & $\begin{array}{l}7.1 \\
5.8 \\
6.0 \\
6.1 \\
6.05\end{array}$ & $\begin{array}{l}0.29 \\
1.08 \\
0.95 \\
0.67 \\
0.58\end{array}$ & $\begin{array}{r}480 \\
0 \\
720 \\
840 \\
519\end{array}$ & $\begin{array}{l}0.78 \\
1.09 \\
1.79 \\
1.72 \\
1.42\end{array}$ & $\begin{array}{c}18.1 \\
0 \\
27.2 \\
31.7 \\
20.2\end{array}$ & $\begin{array}{r}34 \\
0 \\
52 \\
60 \\
37\end{array}$ & $\begin{array}{r}3 \\
0 \\
105 \\
5 \\
3\end{array}$ & \begin{tabular}{|r|}
5 \\
0 \\
108 \\
54 \\
6
\end{tabular} & $\begin{array}{r}1 \\
0 \\
2 \\
47 \\
2\end{array}$ & $\begin{array}{c}+0.05 \\
-0.75 \\
+0.14 \\
0.0 \\
-0.06\end{array}$ & $\begin{array}{r}+1.9 \\
+23.7 \\
-2.7 \\
+9.2 \\
+0.4\end{array}$ & $\begin{array}{r}-2 \\
-54 \\
+5 \\
+14 \\
-4\end{array}$ & $\begin{array}{r}-2 \\
-71 \\
+88 \\
-1 \\
0\end{array}$ & $\begin{array}{l}-11 \\
-60 \\
+64 \\
+7 \\
-8\end{array}$ & $\begin{array}{l}-\quad 4 \\
=\quad 57 \\
-\quad 27 \\
+\quad 39 \\
-\quad 1\end{array}$ \\
\hline $\begin{array}{l}4 \mathrm{~A} \\
4 \mathrm{~B} \\
4 \mathrm{C} \\
4 \mathrm{D}\end{array}$ & $\begin{array}{l}5 \\
7 \\
7 \\
7\end{array}$ & $\begin{array}{l}12.2 \\
11.1 \\
10.5 \\
10.1\end{array}$ & $\begin{array}{l}0.36 \\
0.91 \\
1.24 \\
0.86\end{array}$ & $\begin{array}{r}259 \\
0 \\
308 \\
152\end{array}$ & $\begin{array}{l}0.77 \\
1.61 \\
1.77 \\
1.46\end{array}$ & $\begin{array}{c}9.8 \\
0 \\
11.7 \\
5.7\end{array}$ & $\begin{array}{r}19 \\
0 \\
22 \\
11\end{array}$ & $\begin{array}{r}1 \\
0 \\
128 \\
1\end{array}$ & \begin{tabular}{|r|}
3 \\
0 \\
103 \\
106
\end{tabular} & $\begin{array}{r}1 \\
0 \\
3 \\
105\end{array}$ & $\begin{array}{l}-0.04 \\
-0.66 \\
-0.03 \\
+0.23\end{array}$ & $\begin{array}{r}-6.2 \\
=30.0 \\
=3.0 \\
-6.1\end{array}$ & $\begin{array}{l}-1 \\
=55 \\
-13 \\
-16\end{array}$ & $\begin{array}{r}-3 \\
-95 \\
+85 \\
-12\end{array}$ & $\begin{array}{l}-3 \\
-78 \\
+56 \\
+30\end{array}$ & $\begin{array}{l}-14 \\
=46 \\
\overline{1} 39 \\
+\quad 24\end{array}$ \\
\hline $\begin{array}{ll}5 & \mathrm{~A} \\
5 & \mathrm{~B} \\
5 & \mathrm{C} \\
5 & \mathrm{C} \\
5 & \mathrm{D} \\
5 & \mathrm{D}\end{array}$ & $\begin{array}{l}3 \\
7 \\
7 \\
7 \\
7 \\
7\end{array}$ & $\begin{array}{l}7.4 \\
6.5 \\
6.8 \\
6.6 \\
6.8 \\
6.8\end{array}$ & $\begin{array}{l}0.31 \\
0.90 \\
0.58 \\
0.45 \\
1.40 \\
1.93\end{array}$ & $\begin{array}{l}405 \\
260 \\
840 \\
560 \\
995 \\
910\end{array}$ & $\begin{array}{l}1.00 \\
1.74 \\
2.38 \\
2.03 \\
3.88 \\
3.94\end{array}$ & $\begin{array}{r}15.5 \\
9.8 \\
31.7 \\
21.2 \\
40.3 \\
37.1\end{array}$ & \begin{tabular}{|r|}
29 \\
19 \\
60 \\
40 \\
114 \\
108
\end{tabular} & $\begin{array}{l}3 \\
2 \\
5 \\
4 \\
6 \\
6\end{array}$ & \begin{tabular}{|r|}
5 \\
3 \\
9 \\
6 \\
118 \\
117 \\
\end{tabular} & $\begin{array}{r}1 \\
1 \\
2 \\
2 \\
152 \\
151\end{array}$ & $\begin{array}{l}-0.06 \\
-0.57 \\
+0.12 \\
-0.11 \\
+0.03 \\
-0.01\end{array}$ & $\begin{array}{r}+3.2 \\
+5.8 \\
+13.3 \\
+6.0 \\
+15.5 \\
+12.3\end{array}$ & $\begin{array}{l}+7 \\
-15 \\
+23 \\
+9 \\
+59 \\
+55\end{array}$ & $\begin{array}{r}-2 \\
-56 \\
+65 \\
-6 \\
-5 \\
0\end{array}$ & $\begin{array}{r}-5 \\
-46 \\
+49 \\
-9 \\
+38 \\
+6\end{array}$ & $\begin{array}{r}-\quad 2 \\
=\quad 9 \\
-\quad 16 \\
0 \\
+117 \\
+\quad 62\end{array}$ \\
\hline
\end{tabular}


trogen, phosphorus and potassium were retained without water.

In order to relate these various changes to one another and to the alteration in concentration of serum electrolyte, it will be necessary to mention certain facts about the distribution of body water and electrolyte.

As has been pointed out by Gamble, Ross and Tisdall (10), when concentrations of serum electrolytes do not vary significantly, changes in body water tend to be associated with proportional changes in the other constituents of the body fluids. Thus if the concentration of body electrolyte remains unaltered, a loss of water from extracellular spaces tends to be associated with excretion of the amount of sodium and chloride dissolved in that amount of extracellular water. Similarly, a loss of intracellular water tends to be accompanied by excretion of the amount of nitrogen, phosphorus and potassium present in that amount of intracellular fluid. The same type of relation should also hold for retentions.

Previous work has indicated that the concentration of extracellular sodium and chloride is measured by the concentrations in serum when corrected for content of water and the Gibbs-Donnan effect (11). Analyses of dog tissues and the application of certain calculations (2) permit a reasonable approximation of the volume and concentration of intracellular fluids. Since muscles constitute the largest single reservoir of intracellular water, for certain purposes intracellular water may be represented by the fluid in muscle cells. Our analyses indicate that the concentration of intracellular water of dog's muscles is as follows: nitrogen, 51 grams; potassium, 141 and phosphorus, $104 \mathrm{mM}$. per liter of water. If balances of potassium, phosphorus and water are assumed to occur in amounts bearing the same relation to nitrogen as was found in muscle cells, the following equations may be used to calculate the expected balances:

(1) $\mathrm{N} \times 0.0198=$ balance of intracellular water

(2) $\mathrm{N} \times 2.77=$ balance of potassium

(3) $\mathrm{N} \times 2.04=$ balance of phosphorus.

$\mathrm{N}$ is expressed in grams, water in liters and potassium and phosphorus in millimoles. Table III compares the balances found with those predicted by the above equations.

Experiment 3 may be used to illustrate the reactions in the experiments with the larger deficits (Experiments 2, 3 and 4). As is shown in Table II, the loss of $71 \mathrm{mM}$. of sodium and $60 \mathrm{mM}$. of chloride was followed by a diminution of 0.75 liter of body water. Since potassium and phosphorus $^{3}$ were also excreted, the change in body

8 In Experiment 4, the balances of $\mathrm{Mg}$ and $\mathrm{Ca}$ were determined. The losses of these elements were so small that they would not significantly alter the osmotic re-
TABLE III

A comparison of the determined balance of water, phosphorus and potassium with the balances calculated from the balances of nitrogen

\begin{tabular}{|c|c|c|c|c|c|c|c|}
\hline \multirow{2}{*}{$\begin{array}{c}\text { Experi- } \\
\text { ment } \\
\text { number } \\
\text { and } \\
\text { period }\end{array}$} & \multirow{2}{*}{$\mathbf{N}$} & \multicolumn{2}{|c|}{ Water } & \multicolumn{2}{|c|}{ Phosphorus } & \multicolumn{2}{|c|}{ Potassium } \\
\hline & & Found & $\begin{array}{l}\text { Calcu- } \\
\text { lated }\end{array}$ & Found & $\begin{array}{l}\text { Calcu- } \\
\text { lated }\end{array}$ & Found & $\begin{array}{l}\text { Calcu- } \\
\text { lated }\end{array}$ \\
\hline $\begin{array}{ll}2 & B \\
2 & C\end{array}$ & $\begin{array}{r}\text { grams } \\
-27 \\
3\end{array}$ & \begin{tabular}{|c} 
liters \\
-0.58 \\
0.26
\end{tabular} & \begin{tabular}{|l}
\multicolumn{1}{|c}{ liters } \\
-0.54 \\
0.06
\end{tabular} & $\begin{array}{r}m M . \\
-60 \\
0\end{array}$ & $\begin{array}{r}m M \\
-55 \\
6\end{array}$ & $\begin{array}{l}m M \\
-50 \\
-27\end{array}$ & $\begin{array}{r}m M . \\
-75 \\
8\end{array}$ \\
\hline $\begin{array}{ll}3 & \text { B } \\
3 & \mathrm{C} \\
3 & \mathrm{D} \\
3 & \mathrm{E}\end{array}$ & $\begin{array}{r}-24 \\
-\quad 3 \\
9 \\
0\end{array}$ & $\begin{array}{c}-0.75 \\
0.14 \\
0.0 \\
-0.06\end{array}$ & $\mid \begin{array}{r}-0.47 \\
-0.06 \\
0.17 \\
0.00\end{array}$ & $\begin{array}{r}-54 \\
5 \\
14 \\
-\quad 4\end{array}$ & $\begin{array}{r}-49 \\
-6 \\
18 \\
0\end{array}$ & $\begin{array}{r}-57 \\
-27 \\
39 \\
-\quad 1\end{array}$ & $\begin{array}{r}-66 \\
-8 \\
25 \\
0\end{array}$ \\
\hline $\begin{array}{l}4 \text { B } \\
4 \stackrel{C}{4} \\
4 \text { D }\end{array}$ & $\begin{array}{l}-30 \\
-3 \\
-6\end{array}$ & $\mid \begin{array}{r}-0.66 \\
-0.03 \\
0.23\end{array}$ & $\begin{array}{r}-0.59 \\
0.06 \\
-0.12\end{array}$ & $\begin{array}{l}-55 \\
-13 \\
-16\end{array}$ & $\begin{array}{l}-61 \\
-6 \\
-12\end{array}$ & $\begin{array}{r}-46 \\
-39 \\
24\end{array}$ & $\begin{array}{l}-83 \\
-8 \\
-16\end{array}$ \\
\hline $\begin{array}{ll}5 & \mathrm{~B} \\
5 & \mathrm{C} \\
5 & \mathrm{C} \\
5 & \mathrm{D} \\
5 & \mathrm{D}\end{array}$ & $\begin{array}{r}-6 \\
13 \\
6 \\
16 \\
12\end{array}$ & $\begin{array}{r}-0.57 \\
0.12 \\
-0.11 \\
0.03 \\
-0.01\end{array}$ & $\begin{array}{r}-0.12 \\
0.25 \\
0.12 \\
0.31 \\
0.24\end{array}$ & $\begin{array}{r}-15 \\
23 \\
9 \\
59 \\
55\end{array}$ & $\begin{array}{r}-12 \\
27 \\
12 \\
33 \\
24\end{array}$ & $\begin{array}{r}-9 \\
-16 \\
0 \\
117 \\
62\end{array}$ & $\begin{array}{r}-16 \\
36 \\
16 \\
44 \\
33\end{array}$ \\
\hline
\end{tabular}

water cannot be directly related to losses of sodium and chloride. Table III shows that the negative balance of nitrogen would account for about two-thirds of the actual loss of water and approximately the same losses of potassium and phosphorus as were found. The water excreted in excess of that presumably associated with nitrogen is sufficient to explain the fact that the concentration of serum electrolyte was partially restored during the $\mathrm{B}$ periods. For complete restoration with the losses of potassium in Experiment 3 , about 0.95 liter of water should have been excreted. Following the administration of sodium chloride, the deficit of extracellular electrolyte was almost exactly replaced and 0.14 liter of water retained in Period C. Since the concentrations of serum electrolyte became normal, the volume of extracellular water must also have returned to the initial value. Hence, the accumulated deficit of water at the end of the $C$ periods must involve chiefly intracellular fluids. Since Table III $(B+C)$ shows that the predicted balances of water, phosphorus and potassium agree essentially with the determined balances of these elements, administration of sodium chloride ap-

lationships. In particular the loss of calcium indicates that the losses of phosphorus must be considered to have come from the cells rather than the bones. 
parently restored a normal state of distribution of water and electrolyte, except for the changes which were referable to fasting. .

Since the diet contained all the elements except potassium which are necessary to rebuild the tissues consumed during the $B$ and $C$ periods, capsules containing definite amounts of potassium chloride were given daily during the $\mathrm{D}$ period. This procedure led to retentions of nitrogen, phosphorus and potassium which agree reasonably well with the balances necessary to restore these elements of cellular structures. However, since no retention of water occurred during the period of observation, complete repair had apparently not taken place.

Experiments 2 and 4 show essentially similar results except that a significant excretion of water beyond that accounted for by the losses of nitrogen, potassium and phosphorus and the consequent concentration of serum electrolyte are not demonstrated in the $B$ periods. Although in the D period of Experiment 4, inadequate consumption of food led to loss of nitrogen and phosphorus, a considerable retention of potassium occurred. In this experiment about two and a half times as much potassium chloride was given as in Experiment 3. In this experiment, retention of water accompanied the positive balance of potassium. Apparently continued loss of nitrogen and phosphorus does not preclude the possibility of retaining potassium.

- In the $B$ periods of Experiment 5, the loss of $56 \mathrm{mM}$. of sodium and $46 \mathrm{mM}$. of chloride was followed by the excretion of 0.57 liter of body water. Since but small losses of nitrogen, potassium and phosphorus occurred, sufficient decrease in body water developed to account for the restoration of the concentrations of serum electrolyte. In the $C$ period, replacement of the deficit of extracellular electrolyte was, however, not accompanied by retention of water. This would indicate that intracellular water was used to restore the volume of extracellular fluids. In view of this finding, it is especially surprising that during the $D$ period a large amount of potassium was retained without water. During the $\mathrm{D}$ period almost $100 \mathrm{mM}$. of potassium were retained in excess of the amount predicted from the balance of nitrogen. However, during the $B$ and $C$ periods, nitrogen and phosphorus had been retained with- out a corresponding balance of potassium. The excess retention of potassium in the $D$ period is such as to restore the accumulated deficit of this ion with respect to nitrogen and phosphorus.

The lack of retention of water during the $C$ and $\mathrm{D}$ periods in this experiment is hard to reconcile with concepts of osmotic equilibrium. During the 56 days of Experiment 5 the balance of nitrogen would lead one to expect a retention of about 0.8 liter of water, but actually a loss of about 0.57 liter occurred. The discrepancy between the determined and predicted balances of water is of the same order of magnitude if calculated from the retention of potassium. In spite of this increase in body potassium without change in body water, osmolar concentration of body water as measured by the concentration of serum sodium remained essentially unaltered. Similar but less striking discrepancies between predicted and determined balances of water may be noted in the other experiments. Table III shows that the divergencies between the predicted and determined balances of water, phosphorus and potassium diminish when Periods $\mathrm{B}$ and $\mathrm{C}$ are summated. Periods of 7 days may be too short for complete adjustments to take place but it is not certain that longer periods would make all balances of nitrogen, phosphorus, potassium and water occur in constant relations to each other.

\section{DISCUSSION}

The present data confirm the work of Gamble, Ross and Tisdall (10) and the concepts elaborated in our previous publication and those of Peters and Lavietes and others $(11,12,13)$. Gamble, Ross and Tisdall found that during the early stage of starvation, loss of potassium occurred in excess of the corresponding loss of nitrogen. During subsequent days, loss of potassium was somewhat less than the corresponding loss of nitrogen so that, at the end of 15 days, the accumulated deficits of nitrogen and potassium had occurred in amounts proportional to their concentration in muscle cells. In these experiments concentration of serum base remained constant and the loss of water could be predicted by the loss of sodium and potassium. In certain of their studies Lavietes, D'Esopo and Harrison (13) were able approximately to account for changes in the concentration 
of serum electrolyte from the balances of water, sodium and potassium. When similar calculations were carried out on the data in this study, predicted concentrations in serum agreed relatively closely with determined values in some instances but in others widely divergent values were obtained. This discrepancy is most marked in Experiment 5 in which the retention of 179 $\mathrm{mM}$. of potassium without water was associated with no significant changes in concentration of serum electrolyte. Such calculations assume a relatively constant relation between the concentration of sodium in serum and potassium in intracellular water. While osmotic equilibrium between extracellular and intracellular fluid is undoubtedly maintained, variations in the combinations of potassium in the cells may so alter its dissociation as to change the osmotic pressure exerted by a given amount of potassium. Furthermore, the function of the large amount of osmotically inactive sodium (2) in bone and cartilage must be determined before balances of sodium can be assumed to involve only the sodium of extracellular fluids. The present data indicate that the relation of the concentration of serum sodium to that of intracellular potassium must fluctuate rather widely and that loss of nitrogen, phosphorus and potassium can occur independently of each other and of water. Changes in body potassium without change in body water may occur when no significant alteration in concentration of serum electrolyte can be demonstrated. When observations are carried out over longer intervals it may be possible to demonstrate that these substances tend to be retained or lost so as to maintain tissue structures of fairly uniform composition. However, in babies, increased intake of minerals has been shown to lead to increased retentions over long periods (14). Peters and Lavietes (12) point out that the relation of body water to tissue solids does not remain constant during periods of changing nutrition and the organism does not give off or take on water in exact mathematical proportions to gains or losses of protein, carbohydrate and fat. Our experiments support these concepts and indicate that balance of body water is not predicted from balances of potassium. However, support is given to the idea that balances of nitrogen, phosphorus and potassium tend to bear fairly constant rela- tions to each other under the circumstances of our experiments.

The tables show that, when administration of potassium chloride led to retention of potassium, practically all the chloride was excreted. Since by actual determinations as well as theoretical considerations, potassium concentration in extracellular fluids did not increase, the potassium undoubtedly was retained by the cells. These facts support the concept that chloride is probably exclusively extracellular (2).

The present experiments throw light on the physiological adjustments to loss of extracellular electrolyte. In our previous publication the initial response to loss of extracellular electrolyte without water was shown to be maintenance of osmotic equilibrium between extracellular and intracellular fluids by shift of water from the former into the latter. Experiments 2, 3 and 4 show that this state of hydration of intracellular fluids and dehydration of extracellular fluids may persist for a week. The loss of water found in these experiments is practically entirely accounted for by loss of intracellular constituents in the proportions existing in muscle cells. Tissue destruction during starvation explains these losses. In other words the volume of body water was preserved by permitting a decreased concentration of electrolyte to persist.

In Experiment 5, the loss of $55 \mathrm{mM}$. of sodium led to the excretion of 0.5 liter of water and negligible losses of nitrogen, potassium and phosphorus. Since the concentration of serum sodium was practically restored, the water excreted must have come from the extracellular fluids. The same type of adjustment to moderate losses of extracellular electrolyte, has been demonstrated by Kerpel-Fronius (15), who reported complete restoration of the concentration of serum sodium by excretion of water following the production of deficits of extracellular electrolyte by our technique.

In none of the experiments was potassium not accounted for by loss of nitrogen excreted along with water. Were this to occur, the shift of water into the cells would be avoided, and the volume of intracellular fluid would be protected at the expense of cellular potassium. Loss of potassium without corresponding loss in nitrogen is reported in diabetic coma (16), infantile diarrhea (17), 
and accompanying the administration of acidifying diuretics (18). It is unlikely that in these instances the loss of potassium is a response to the deficit of extracellular electrolyte. It is more probably related to the disturbances associated with other factors, such as acidosis or disturbances in function or composition of cells.

As in most physiological adjustments, loss of extracellular electrolyte leads to a compromise in which neither volumes nor concentrations of body fluids are restored. Replacement of all substances withdrawn are necessary before body fluids can become normal.

\section{SUMMARY}

Dogs were subjected for periods of a week or more to the following procedures: (1) deficit of extracellular electrolyte, (2) replacement of deficit of extracellular electrolyte and (3) administration of $\mathrm{KCl}$. The concentrations of serum electrolyte and the balances of water, $\mathrm{Na}, \mathrm{Cl}, \mathrm{K}$ and $\mathrm{P}$ were determined.

Symptoms and signs of dehydration were produced by deficit of extracellular electrolyte and persisted until $\mathrm{NaCl}$ was administered. Loss of appetite was a striking symptom of the deficit.

Loss of nitrogen, phosphorus, potassium and water accompanied deficit of sodium and chloride. The proportions of these components in the losses were approximately the same as the proportions found in muscle cells of a dog indicating that these losses were chiefly the result of starvation.

With a large deficit of sodium and chloride little restoration of concentration of serum electrolyte occurred, but with a smaller loss, enough water was excreted almost to restore the concentration of electrolyte in serum.

Retentions of potassium, phosphorus and nitrogen unaccompanied by a corresponding increase in body water were demonstrated.

\section{PROTOCOLS}

Experiment 2. Dog 2, fat female. At the beginning of Period B, 1.15 liters of 5 per cent solution of glucose were injected into the peritoneal cavity and 1 liter removed 4 hours later. The loss by this procedure was $\mathrm{Na}$, 85.8, Cl, 73.2 and $\mathrm{K}, 2.4 \mathrm{mM}$. The dog was quite sick with symptoms and signs of dehydration during Period B. At the beginning of Period C, 0.5 liter of water containing $103 \mathrm{mM}$. of $\mathrm{NaCl}$ was injected into the peri- toneal cavity. Appetite and well-being were restored within 12 hours after this injection.

Experiment 3. Dog 1, thin male. At the beginning of Period B, 0.75 liter of 5 per cent solution of glucose was injected into the peritoneal cavity and 0.76 liter removed 4 hours later. The losses were $\mathrm{Na}, 68, \mathrm{Cl}, 57.4$ and $\mathrm{K}, 1.4 \mathrm{mM}$. The dog showed marked signs and symptoms of dehydration during Period B. At the beginning of the $\mathrm{C}$ period, 0.33 liter of a solution containing $100 \mathrm{mM}$. $\mathrm{NaCl}$ was injected into the peritoneal cavity. Recovery was obvious within 12 hours. During the first 24 hours following the injection of the salt solution, $540 \mathrm{cc}$. of urine were excreted. During the D period, capsules containing $44.3 \mathrm{mM}$. $\mathrm{KCl}$ were given each day. Period $\mathrm{E}$ serves as a control.

Experiment 4. Dog 2, fat female. At the beginning of Period B, 1.25 liters of a 5 per cent solution of glucose was injected into the peritoneal cavity and 1.0 liter removed 4 hours later. The losses were $\mathrm{Na}, 91.0$, $\mathrm{Cl}, 74.1$ and $\mathrm{K}, 3.4 \mathrm{mM}$. Marked symptoms and signs of dehydration persisted throughout Period B. At the beginning of Period C, 0.4 liter of a solution containing $\mathrm{Na}, 126, \mathrm{Cl}, 100$ and $\mathrm{K}, 2 \mathrm{mM}$. was injected into the peritoneal cavity. During Period D, $104.7 \mathrm{mM}$. of $\mathrm{KCl}$ were given in six capsules. Although the dog ate poorly throughout the experiment, she seemed well except during Period B.

Experiment 5. Dog 1, thin male. At the beginning of Period B, 0.70 liter of a 5 per cent solution of glucose was injected into the peritoneal cavity and 0.48 liter removed 4 hours later. The losses were $\mathrm{Na}, 51.1, \mathrm{Cl}$, 43.4 and $\mathrm{K}, 1.5 \mathrm{mM}$. The dog was somewhat less active for about 2 days but thereafter activity and appetite returned to normal. At the beginning of Period C, 0.25 liter of a solution containing $77 \mathrm{mM}$. of $\mathrm{NaCl}$ was injected into the peritoneal cavity. The animal was followed for two successive weeks. During Period D, 104.7 mM. of $\mathrm{KCl}$ and 175 grams of "Embo" were given each week.

\section{BIBLIOGRAPHY}

1. Darrow, D. C., and Yannet, H., The changes in the distribution of body water accompanying increase and decrease in extracellular electrolyte. J. Clin. Invest., 1935, 14, 266.

2. Harrison, H., Darrow, D. C., and Yannet, H., The total electrolyte content of animals and its probable relation to the distribution of body water. J. Biol. Chem., 1936, 113, 515.

3. Peters, J. P., and Van Slyke, D. D., Quantitaive Clinical Chemistry. Vol. II. Methods. Williams and Wilkins Co., Baltimore, 1932, p. 519.

4. Ibid. Page 834 .

5. Ibid. Page 858.

6. Ibid. Page 732 .

7. Hald, P. M., The determination of the bases of serum and whole blood. J. Biol. Chem., 1933, 103, 471.

8. Peters, J. P., Kydd, D. M., and Lavietes, P. H., A 
note on the calculation of water exchange. J. Clin. Invest., 1933, 12, 689.

9. Cowgill, G. R., The energy factor in relation to food intake. Experiments on the dog. Am. J. Physiol:; 1928, 85, 45.

10. Gamble, J. L., Ross, G. S., and Tisdall, F. F., The metabolism of fixed base during fasting. J. Biol. Chem., 1923, 57, 633.

11. Peters, J. P., Body Water. Charles C. Thomas, Springfield, Ill., 1935, p. 60.

12. Peters, J. P., and Lavietes, P. H., The nature of "preformed water." J. Clin. Invest., 1933, 12, 695.

13. Lavietes, P. H., D'Esopo, L. M., and Harrison, H. E., The water and base balance of the body. J. Clin. Invest., 1935, 14, 251.

14. Swanson, W. W., The composition of growth. II.
The full-term infant. Am. J. Dis. Child., 1932, 43, 10.

15. Kerpel-Fronius, E., Uber die Beziehungen Zwischen Salz- und Wasserhaushalt bei experimentellen Wasserverlusten. Ztschr. f. Kinderh., 1935, 57, 489.

16. Atchley, D. W., Loeb, R. F., Richards, D. W., Jr., Benedict, E. M., and Driscoll, M. E., On diabetic acidosis. A detailed study of electrolyte balances following the withdrawal and reestablishment of insulin therapy. J. Clin. Invest., 1932, 12, 297.

17. Butler, A. M., McKhann, C. F., and Gamble, J. L., Intracellular fluid loss in diarrheal disease. J. Pediat., 1933, 3, 84.

18. Gamble, J. L., Blackfan, K. D., and Hamilton, B., A study of the diuretic action of acid producing salts. J. Clin. Invest., 1925, 1, 359. 